\title{
SUBALPINE BEECH FOREST WITH HAIRY ALPENROSE (POLYSTICHO LONCHITIS-FAGETUM RHODODENDRETOSUM HIRSUTI SUBASS. NOVA) ON MT. SNEŽNIK (LIBURNIAN KARST, DINARIC MTS)
}

\author{
Boštjan SURINA* \& Marash RAKAJ**
}

\begin{abstract}
Subalpine beech stands with Hairy Alpenrose (Rhododendron hirsutum) were phytosociologically studied on Mt. Snežnik (Dinaric Mts). They thrived on stony and steep slopes of northern exposure. Comparisons with other subalpine Beech stands (Polysticho lonchitis-Fagetum s. lat.), Dinaric Fir-Beech stands with Hairy Alpenrose (Omphalodo-Fagetum s. lat. rhododendretosum hirsuti), and prealpine fir-beech stands with Hairy Alpenrose (Homogyno sylvestris-Fagetum s. lat. rhododendretosum hirsuti), stands of Hairy Alpenrose and Beech (Rhododendro hirsuti-Fagetum s. lat.), as well as Austrian subalpine beech stands (Saxifrago rotundifoliae-Fagetum s. lat.) showed their unique floristical composition due to ecological conditions, and thus distinct syntaxonomical position within the association Polysticho-Fagetum. Therefore, a new subassociation Polysticho-Fagetum rhododendretosum hirsuti subass. nova was described, and - as differential species for the subassociation - Rhododendron hirsutum, Rubus saxatilis, Rosa pendulina, and Clematis alpina were chosen.

Key words: Dinaric Mts, Mt. Snežnik, Polysticho-Fagetum, subalpine beech forest, Rhododendron hirsutum, vegetation

Izvleček

Prispevek podaja fitocenološko oznako subalpinskega bukovega gozda (Polysticho lonchitis-Fagetum) z dlakavim slečem (Rhododendron hirsutum) na Snežniku. Obravnavani sestoji uspevajo na kamnitih in/ali skalnatih ter strmih pobočjih severnih ekspozicij. Primerjave z ostalimi subalpinskimi bukovimi ter (jelovo-)bukovimi sestoji z dlakavim slečem (Omphalodo-Fagetum rhododendretosum hirsuti, Homogyno sylvestris rhododendretosum hirsuti, Rhododendro-Fagetum) ter subalpinskimi bukovji iz Avstrije (Saxifrago rotundifolii-Fagetum) so pokazale njihov poseben sintaksonomski položaj v okviru asociacije Polysticho-Fagetum. Zato smo te sestoje uvrstili v novo subasociacijo Polysticho-Fagetum rhododendretosum hirsuti subass. nova, za razlikovalnice pa izbrali vrste Rhododendron hirsutum, Rubus saxatilis, Rosa pendulina in Clematis alpina.
\end{abstract}

Ključne besede: Dinaridi, Snežnik, Polysticho-Fagetum, subalpinski bukov gozd, Rhododendron hirsutum, vegetacija

\section{INTRODUCTION}

Subalpine beech forests in Dinaric Mts: a brief synsystematic overview

Horvat (1938) classified beech forests in NW Dinaric Mts into three subassociations, namely: (a) montane beech forests Fagetum sylvaticae croaticum australe montanum, (b) montane and altimontane Dinaric fir-beech forests Fagetum sylvaticae croaticum australe abietetosum, and (c) subalpine beech for- ests Fagetum sylvaticae croaticum australe subalpinum. Subsequent studies clearly showed that Horvat's classification of beech forests from the alliance Aremonio-Fagion (= Fagion illyricum) was too broad; consequently, beech forest subassociations were ranked as associations and several new floristically and ecologically more or less well defined associations were described (e.g. Tregubov 1957, Košir 1979, Marinček 1983, 1996, Dakskobler 1997, Marinček 1998).

\footnotetext{
* University of Vienna, Faculty of Life Sciences, Department of Biogeography, Rennweg 14, A-1030 Vienna, Austria Natural History Musem Rijeka, Lorenzov prolaz 1, 51000 Rijeka, Croatia. Bostjan.Surina@univie.ac.at ** Universiteti i Shkodrës »Luigj Gurakuqi«, Departimenti Biologji-Kimisë, Shkodër, Albania
} 
After the nomenclature revision of the alliance Aremonio-Fagion (Marinček et al. 1993, but see also Poldini \& Nardini 1993), the subalpine beech association (Fagetum sylvaticae croaticum australe subalpinum Horvat 1938) was split into two new associations: Ranunculo platanifolii-Fagetum (altimontane belt) and Polysticho lonchitis-Fagetum (extrazonally on exposed and/or northern slopes in altimontane belt, but commonly (zonally) in subalpine belt up to the forest line). There were attempts to further phytogeographically differentiate association Polysticho-Fagetum into geographical variants: (a) Anemone trifolia (Poldini \& Nardini 1993) for NE Italy and W Slovenia, (b) Salix waldsteiniana (Marinček 1996) for the south-eastern foothills of the Julian Alps (namely Mts Blegoš and Ratitovec), and (c) Allium victorialis (Marinček 1996) for the Dinaric Mts, but according to our analyses they seemed to be of low synsystematic significance.

\section{Subalpine beech forests on Mt. Snežnik}

Tomažič was one of the first who studied subalpine beech stands on Mt. Snežnik but unfortunately the results (i.e. phytosociological tables) were never published (e.g. Zupančič 2001). Nevertheless, together with colleagues he successfully conducted extensive vegetation mappings throughout the study area and, as a result, detailed vegetation maps were provided (Tomažič \& Tregubov 1958, 1959). He classified subalpine beech stands into the association Allio victorialis-Fagetum Tomažič nom. nud., and mapped them throughout the southern part of the Snežnik plateau. Afterwards, Tregubov (1957) provided three relevés (from Kujavič, Drče and NE slopes of the summit) and classified them within the association Fagetum subalpinum (sensu Horvat 1938). Only in 1996 Marinček published 29 relevés of subalpine beech stands from the plateaus of Trnovski gozd and Snežnik (NW Dinaric Mts), classifying them into the geographical variant PolystichoFagetum var. geogr. Allium victorialis, he recognised three subassociations: - polystichetosum (with variants Gymnocarpium dryopteris and Adoxa moschatellina), -adenostyletosum alliariae, and -hacquetietosum. Unfortunately, from the phytosociological table it is hardly possible to distinguish localities of relevés between the plateaus of Trnovski gozd and Snežnik.

One of the most distinctive characteristics of subalpine beech stands (beside the floristic composition) is their unique physiognomy. Specially on the upper limit of their altitudinal range (forest line), distorted, twisted stems and curved branches of beech trees make stands appear picturesque. Due to harsh environmental conditions (strong Bora, low winter temperature and heavy snowfalls) beech stands rarely exceed $3-5 \mathrm{~m}$ in height and $10-30 \mathrm{~cm}$ in trunk diameter.

Subalpine beech stands of Polysticho-Fagetum are fairly widespread throughout the plateau, but they rarely (only above 1300-1400 m a.s.l. and mostly on the southern part of the Snežnik plateau) extend over larger areas. They usually thrive on mountain ridges, summits and northern slopes of mountains between 1300-1500 (1600) m a.s.l., forming a distinct forest line in direct contact with stands of Mountain pine (Hyperico grisebachii-Pinetum mugo var. geogr. Arabis scopoliana), as well as Dinaric subalpine tussock grasslands (alliance Seslerion juncifoliae). Probably, as a consequence of pasture activites in $19^{\text {th }}$ century (according to Smerdel 1989), the upper altitudinal limit of stands (forest line!) might have been significantly lowered (e.g. Kindler 1957, Pogačnik \& Prosen 1998). Subalpine beech stands may well occur also on lower altitudes of the plateau in freezing ravines as a result of extreme ecological conditions due to temperature inversion (Surina \& Vreš 2004). On the other hand, the transition area on the lower altitudinal limit of stands might extend (mostly on northerly exposed and colder slopes) well into the altitudinal range of stands of other syntaxa (namely Ranunculo-Fagetum var. geogr. Calamintha grandiflora) and/or Omphalodo-Fagetum var. geogr. Calamintha grandiflora), and thus making sufficient delimitation of stands of different syntaxa (specialy Ranunculo-Fagetum) hardly possible.

During our research on flora and vegetation of the Liburnian karst we noticed on several occasions physiognomically, floristically and ecologically distinct subalpine beech stands with predominating Hairy Alpenrose (Rhododendron hirsutum) in shrub and/or herb layer thriving on steep, rocky and most frequently northerly exposed slopes. The aim of the present study was thus to determine their ecological and syntaxonomical position in comparison to other similar (fir-) beech stands with Hairy Alpenrose within the alliance Aremonio-Fagion.

\section{Study area}

The Snežnik plateau is a high-karst region in the northwesternmost part of the Liburnian karst (NW Dinaric Mts, SW Slovenia). The highest mountain of the plateau is Mt. Snežnik (1796 m), which creates a 
distinctive orographic barrier between the northern and the southern part of the plateau. On average, the higher (and also with more diversified relief) southern part of the plateau received considerably higher amounts of precipitation (Gomance, $937 \mathrm{~m}$, $3143 \mathrm{~mm}$ ) than its northern part (Leskova dolina, $806 \mathrm{~m}, 2166 \mathrm{~mm}$ ), while the entire region is among the wettest in Slovenia (Manohin 1957, Zupančič 1995). The precipitation regime of the southern part is strongy influenced by the Mediterranean. On account of the higher altitude of the plateau, karst relief, windness and abundant rainfall the climate is relatively cold. The mean temperature of Gomance was $6.7^{\circ} \mathrm{C}$ (Mekinda-Majaron 1995), and the vegetation season lasts from May till September.

The geological bedrock consists of Jurassic and Cretaceous limestones, dolomitized limestones and their breccias (Pleničar 1956, Pavlovec \& Pleničar 2000). At the time of the last glacial period the larger part of the study area was located above the perpetual snow line (Sifrer 1959).

For detailed microclimatic and general vegetation descriptions of the study area compare also Zupančič $(1970,1980)$, Wraber (1997) and Surina \& Vreš (2004).

\section{METHODS}

Between 2002 and 2005 we made 11 relevés of subalpine beech stands on Mt. Snežnik applying the sigmatistic method (Braun-Blanquet 1964, Dierschke 1994). When arranging the relevés into a phytosociological table and comparing them with the stands of similar syntaxa we used the hierarchical classification (complete linkage method (farthest neighbour) - FNC, incremental sum of squares -ISSq, and unweighted average linkage method - UPGMA), and principal coordinates analysis (PCoA) within the SYN-TAX programme package (Podani 2001). For this purpose we transformed cover values with van der Maarel's numerical (1-9) scale (van der Maarel 1979). The measures of dissimilarity were a complement of the "similarity ratio« coefficient and »Euclidian distance «.

On the final arrangement of relevés (Tab. 1) we combined the results obtained by numerical methods with the arrangement based on diagnostic species. The phytosociological groups were generally in agreement with numerous authors but formed on our own criteria. The nomenclature source for the names of vascular plants was the Mala flora Slovenije (Martinčič et al. 1999), while names for mosses and lichens were in agreement with the Annotated check-list of the mosses of Slovenia (Martinčič 2003), and the Catalogue of the lichenised and lichenicolous fungi of Slovenia (Suppan et al. 2000). Only the most common taxa of mosses and lichens were determined and therefore excluded from the numerical analyses. For the names of syntaxa we followed Marinček et al. (1993) with some minor annotations, but the complete list is given in an appendix.

Subalpine beech stands with Hairy Alpenrose from Mt. Snežnik were compared with some similar beech communities in the Northeastern and Southeastern Alps, and in the Dinaric Mts:

1. Polysticho lonchitis-Fagetum s. lat.:

Italy: Friuli (Poldini \& Nardini 1993); Slovenia:

Mts Blegoš and Ratitovec (Marinček 1980), Mt. Snežnik (Tregubov 1957), and Snežnik and Trnovski gozd plateaus (Marinček 1996); Croatia: Velebit Mts (Horvat 1938);

2. Omphalodo-Fagetum var. geogr. Saxifraga cuneifolia rhododendretosum hirsuti: Slovenia, Trnovski gozd plateau (Dakskobler et al. 2000);

3. Homogyno sylvestris-Fagetum var. geogr. Anemone trifolia rhododendretosum hirsuti, and Homogyno sylvestris-Fagetum var. geogr. Luzula nivea rhododendretosum hirsuti; Slovenia, Julian Alps (Dakskobler 2002, 2004);

4. Rhododendro hirsuti-Fagetum var. geogr. Anemone trifolia \& var. geogr. Phyteuma columnae: Slovenia, NW Dinaric Mts and Julian Alps (Dakskobler 2003).

5. Saxifrago rotundifoliae-Fagetum Zukrigl $1989 \mathrm{~s}$. lat.: Austria, NE and SE Alps (Willner 2007).

The synoptic table is available within electronic appendix.

\section{RESULTS AND DISCUSSION}

Floristic composition and physiognomic aspect of stands

In the tree layer Fagus sylvatica ${ }^{4-5}$ completely prevailed, reaching up to 10-15 $\mathrm{m}$ in height and 10-30 $\mathrm{cm}$ of trunk diameter. Basal parts of beech-trunks, specially on slopes, were typically curved due to pressure of the heavy and long-lasting snow cover. Sorbus aria ${ }^{+}$occurred frequently in the studied stands, albeit with rather low coverage value. Less frequent and with low cover values were Acer pseudoplatanus ${ }^{+}$, Abies alba ${ }^{+}$, Picea abies ${ }^{+}$, and Sorbus aucuparia ${ }^{+}$.

Among the shrub species (occurring in shrub and/or herb layer) Rhododendron hirsutum ${ }^{1-4}$ totaly 
dominated in stands and together with Fagus sylvatica (in tree layer), Lonicera alpigena ${ }^{+-2}$, Rosa pendulina $^{+-3}$, Daphne mezereum ${ }^{+1}$, Salix appendiculata ${ }^{+-1}$, and Rubus saxatilis ${ }^{+-2}$ most significantly contributed to the physiognomic aspect of stands.

Herb layer was well developed. Clematis alpina ${ }^{1-2}$, Anemone nemorosa ${ }^{1-2}$, Valeriana tripteris ${ }^{+-2}$, Homogyne sylvestris ${ }^{1-2}$, Adenostyles glabra $^{+-2}$, Phyteuma ovatum ${ }^{+-2}$, and Calamagrostis varia ${ }^{1-2}$ dominated with rather high coverage values, whereas Polystichum lonchitis $^{+-1}$, Cardamine enneaphyllos ${ }^{+-1}$, Euphorbia carniolica ${ }^{+}$, Cardamine trifolia ${ }^{+-1}$, Festuca altissima ${ }^{+-1}$, Mercurialis perennis ${ }^{+-1}$, Polygonatum verticillatum ${ }^{+-1}$, Gentiana asclepiadea $^{+-1}$, and Solidago virgaurea ${ }^{+}$occurred quite frequently but with smaller coverage values.

Moss layer covered 5-20\% of the relevé area and the most frequent species were Ctenidium molluscum $^{1-2}$, Tortella tortuosa ${ }^{+-1}$, and Schistidium apocarpum $^{+-1}$.

The complete floristic composition of the studied stands is given in the phytosociological table (Tab. 1).

Characteristic and differential species of the association Polysticho lonchitis-Fagetum are fully represented, with Polystichum lonchitis being the most $(100 \%)$ and Ribes alpinum (36\%) the least frequent.

The number of seed plants per relevé varied between 35 and 56, with the median of 47, and the coefficient of variation of $16.14 \%$, indicating a quite uniform floristical composition of stands.

\section{Ecology of stands}

Most frequently stands thrived on northerly exposed slopes (Tab. 1). Slopes were moderately steep to very steep with inclination varying between $15^{\circ}$ and $50^{\circ}(\mathrm{Me}=35 \%)$. Stoniness made up a large proportion of relevé areas $(10-70 \%, \mathrm{Me}=40 \%)$. In comparison to other (fir-) beech and subalpine beech stands in the studied area, we noticed considerable delay in phenophases in subalpine stands with predominating Rhododendron hirsutum, most probably due to unfavourable ecological conditions. Dolomitized limestones and limestone prevailed.

\section{Synsystematic position of studied stands}

Firstly, in order to accurately determine the synsystematic position of the studied stands, we performed comparisons with stands of the subalpine beech association Polysticho-Fagetum in Slovenia and Croatia (Fig. 1).

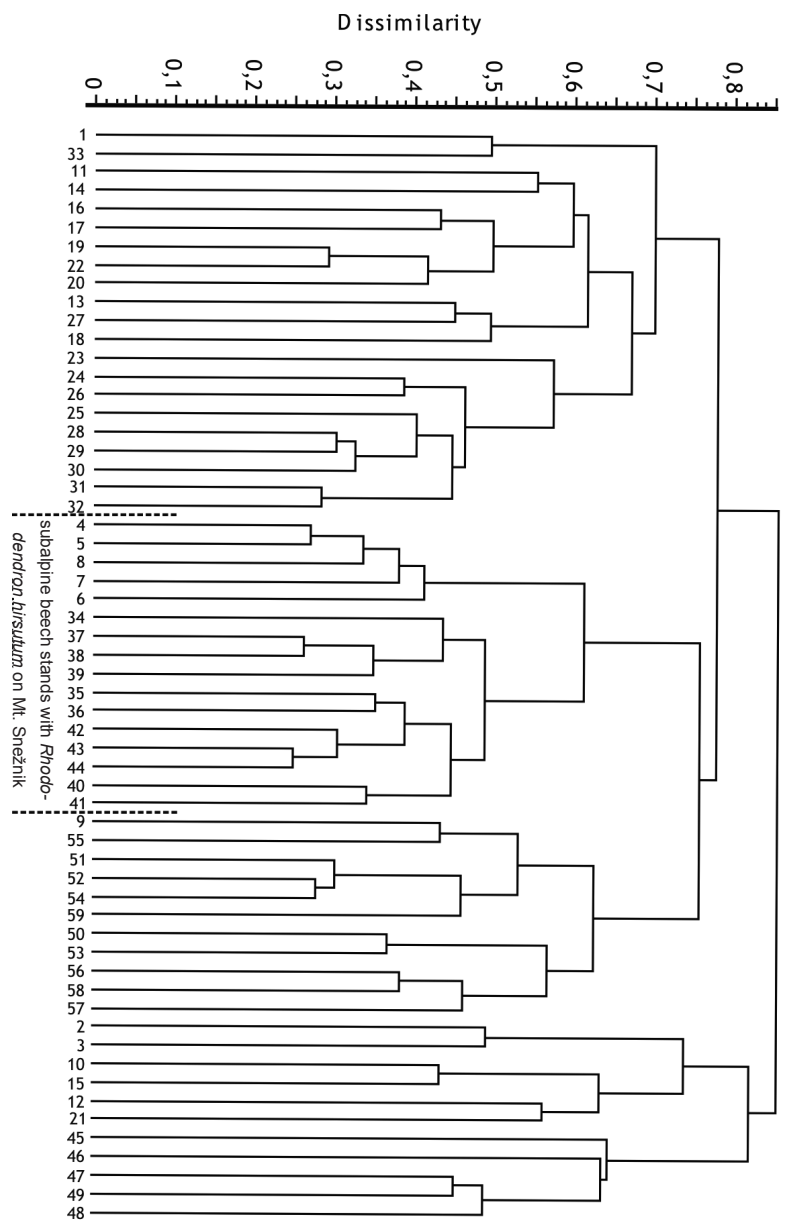

Figure 1: Dendrogram of the subalpine beech stands (Polysticho-Fagetum s. lat.) in the Julian Alps and Dinaric Mts (complete linkage, similarity ratio); 1-3: Mt. Snežnik (Tregubov 1957), 4-33: Snežnik and Trnovski gozd plateaus (Marinček 1996), 34-44: Mt. Snežnik (Surina, this work), 45-49: NE Italy (Poldini \& Nardini 1993), 50-59: Mts Blegoš and Ratitovec (Marinček 1981).

Slika 1: Dendrogram subalpinskih bukovih sestojev (Polysticho-Fagetum s. lat.) v Julijskih Alpah in Dinaridih (complete linkage, similarity ratio); 1-3: Snežnik (Tregubov 1957), 4-33: Snežnik in Trnovski gozd (Marinček 1996), 34-44: Snežnik (Surina, to delo), 45-49: SV Italija (Poldini \& Nardini 1993), 50-59: Blegoš in Ratitovec (Marinček 1981).

Stands from the Snežnik plateau with predominating Rhododendron hirsutum nested in a separate cluster, supporting their distinct synsystematic position, and were -somewhat surprisingly- most similar to stands from Mt. Blegoš. Some relevés from the phytosociological table of Marinček (1996; rel. 1-5; -polystichetosum, var. Gymnocarpium dryopteris) joined the cluster with the studied stands and therefore were treated separately in subsequent analyses. 


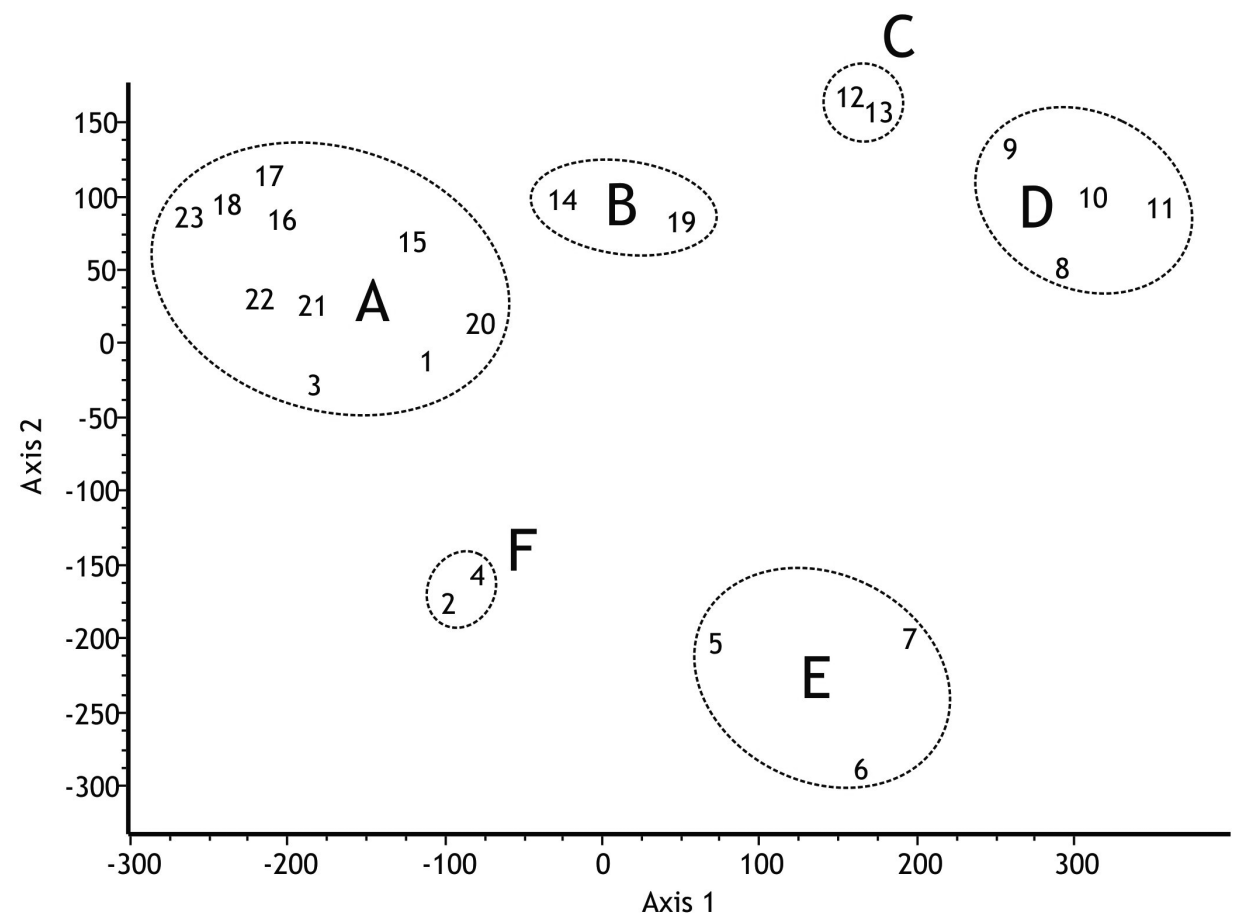

Figure 2: Two-dimensional scatter-diagram of subalpine (fir-) beech stands with Hairy Alpenrose (Rhododendron hirsutum) in the Julian Alps, NE and SE Alps in Austria, and Dinaric Mts (PCoA, Euclidian distance); Polysticho-Fagetum s. lat.: 1 - NE Italy (Poldini \& Nardini 1993), 2 - Mts. Blegoš and Ratitovec (Marinček 1981), 3 - Velebit Mts (Horvat 1938), 4 - Trnovski gozd and Snežnik plateaus (Marinček 1996, rel. 6-29), 5 - Trnovski gozd and Snežnik plateus (Marinček 1996, rel. 1-5), 6 - Mt. Snežnik (Surina, this work); Omphalodo-Fagetum var. geogr. Saxifraga cuneifolia rhododendretosum: 7 - Trnovski gozd plateau (Dakskobler et al. 2000); 8-11 - Rhododendro-Fagetum var. geogr. Anemone trifolia \& var. geogr. Phyteuma columnae (Dakskobler 2003, Tabs. 8, 5, 6 \& 7); Homogyno-Fagetum rhododendretosum: 12-13 - Trnovski gozd plateau and the Julian Alps (Dakskobler 2002, 2004); Saxifrago rotundifoliae-Fagetum s. lat. 14-23 (SE and NE austrian Alps): 14 \& 19 - SaxifragoFagetum calamagrostietosum variae, 15 \& 20 - Saxifrago-Fagetum typicum, 16-21 - Saxifrago-Fagetum adenostyletosum alliariae, 17-22 - Saxifrago-Fagetum petasitetosum, 18-23 - Saxifrago-Fagetum stellarietosum nemorum (Willner \& Grabherr 2007, Tab. 26).

Slika 2: Dvorazsežni ordinacijski diagram subalpinskih (jelovo-) bukovih z dlakavim slečem (Rhododendron hirsutum) v Julijskih Alpah in Dinaridih (PCoA, Euclidian distances); Polysticho-Fagetum s. lat.: 1 - SV Italija (Poldini \& Nardini 1993), 2 - Blegoš in Ratitovec (Marinček 1981), 3 - Velebit (Horvat 1938), 4 - Trnovski gozd in Snežnik (Marinček 1996, rel. 6-29), 5 - Trnovski gozd in Snežnik (Marinček 1996, rel. 1-5), 6 - Snežnik (Surina, to delo); Omphalodo-Fagetum var. geogr. Saxifraga cuneifolia rhododendretosum: 7 - Trnovski gozd in Julijske Alpe (Dakskobler et al. 2000); Rhododendro-Fagetum var. geogr. Anemone trifolia \& var. geogr. Phyteuma columnae: 8-11 - (Dakskobler 2003, Tabs. 8, 5, 6 \& 7); Homogyno-Fagetum rhododendretosum: 12-13 - Julijske Alpe (Dakskobler 2002, 2004); Saxifrago rotundifoliae-Fagetum s. lat. 14-23 (SE and NE austrian Alps): 14 \& 19 - Saxifrago-Fagetum calamagrostietosum variae, 15 \& 20 - Saxifrago-Fagetum typicum, 16-21 - Saxifrago-Fagetum adenostyletosum alliariae, 17-22 - Saxifrago-Fagetum petasitetosum, 18-23 - Saxifrago-Fagetum stellarietosum nemorum (Willner \& Grabherr 2007, Tab. 26).

Secondly, comparisons with other (fir-)beech stands with Rhododendron hirsutum in Slovenia and Austria (Saxifrago-Fagetum) were conducted (Figs. $2 \& 3$, Tab. 2). Again, the results showed the rather unique syntaxonomic position of the studied stands.

Results from the Principal Coordinates Analysis (Fig. 2) generally indicated 6 distinct groups of syntaxa: group A is composed mainly of stands of Saxifrago-Fagetum s. lat., but (somewhat surprisingly) also with stands of Polysticho-Fagetum s. lat. from NE Italy (1) and Velebit Mts - Croatia (3); group B presents stands of Saxifrago-Fagetum calamagrostietosum; group $\mathrm{C}$ is composed of fir-beech stands Homogyno-Fagetum s. lat. from Trnovski gozd plateau and Julian Alps, while group D of stands of Rhododendro-Fagetum. Groups E and $\mathrm{F}$ are composed of stands of Polysticho-Fagetum, where group 


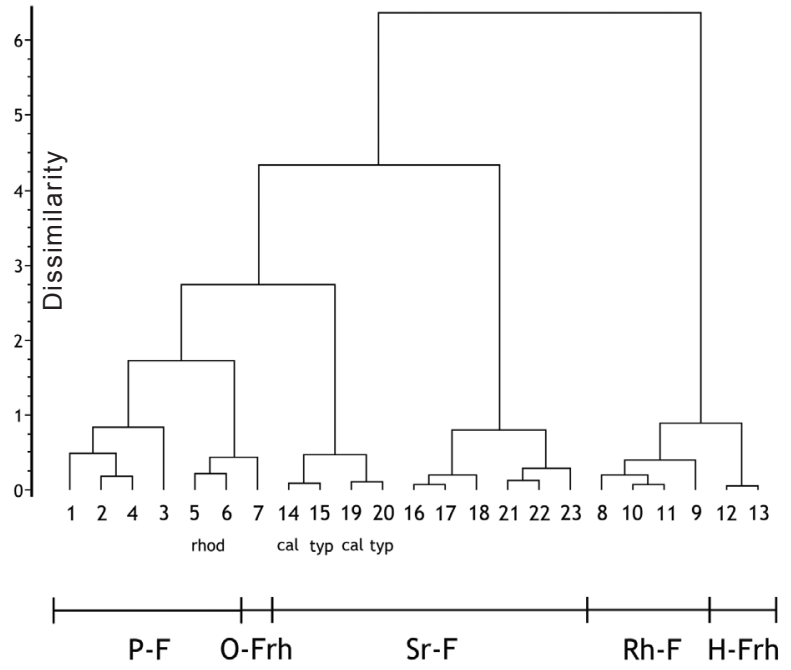

Figure 3: Dendrogram of (fir-)beech syntaxa with Hairy Alpenrose (Rhododendron hirsutum) in the Julian Alps, Austrian NE and SE Alps, and Dinaric Mts (MISSQ, similarity ratio; numbers correspond with Fig. 2).

Slika 3: Dendrogram subalpinskih bukovih gozdov, subalpinskih bukovih gozdov z dlakavim slečem, bukovih gozdov $\mathrm{z}$ dlakavim slečem in jelovo-bukovih sestojev $\mathrm{z}$ dlakavim slečem v Julijskih Alpah, SZ in JV avstrijskih Alpah in Dinaridih (MISSQ, similarity ratio; številke se ujemajo s številkami v sl. 2).
F represents somewhat typical stands, and group E stands of Polysticho-Fagetum (5 \& 6) and Omphalodo-Fagetum var. geogr. Saxifraga cuneifolia (7) with predominating Rhododendron hirsutum in herb or shrub layer. Cluster analysis (Fig. 3) showed slightly different but still similar results. Syntaxa were split into three groups: the first cluster (P-F, O-Frh, and Sr-F cal \& typ) was rather homogeneous and composed mostly from subalpine beech stands (Polysticho-Fagetum s. lat. - 1-6, Saxifrago-Fagetum calamagrostietosum - 14 \& 19 and typicum - 15 \& 20) and dinaric fir-beech forest with Rhododendron hirsutum (Omphalodo-Fagetum var. geor. Saxifraga cuneifolia rhododendretosum hirsuti-7); the second cluster (Sr-F) comprehended syntaxa entirely of Saxifrago-Fagetum - 16-23, while the third cluster (Rh-F and H-Frh) gathered syntaxa of Rhododendro-Fagetum (8-11) and Homogyno-Fagetum (12-13). The studied subalpine beech stands with Rhododendron hirsutum from Mt. Snežnik nested well within subalpine beech stands (Polysticho lonchitis-Fagetum s. lat.), but in a separate cluster (rhod). Not quite unexpectedly, fir-beech stands with Rhododendron hirsutum from the Trnovski gozd plateau (O-Frh) were clustered together with our studied stands (and not separately or even together with pre-alpine fir-beech stands with Rhododendron hirsutum -

Table 2: Phytosociological groups (in \%) in (fir-)beech syntaxa with Hairy Alpenrose (Rhododendron hirsutum) in the Julian Alps and Dinaric Mts (successive numbers from 1-13 correspond to Figs. $2 \& 3$ ).

Tabela 2: Fitocenološke skupine ( $\mathrm{v} \%) \mathrm{v}$ (jelovo-) bukovih sintaksonih z dlakavim slečem (Rhododendron hirsutum) v Julijskih Alpah in Dinaridih (številke od 1 do 13 se ujemajo s sl. 2 in 3).

\begin{tabular}{|c|c|c|c|c|c|c|c|c|c|c|c|c|c|}
\hline Syntaxon & 1 & 2 & 3 & 4 & 5 & 6 & 7 & 8 & 9 & 10 & 11 & 12 & 13 \\
\hline Number of relevés & 5 & 10 & 15 & 25 & 5 & 11 & 15 & 11 & 23 & 26 & 18 & 25 & 19 \\
\hline Number of seed plants & 64 & 102 & 100 & 150 & 64 & 96 & 104 & 119 & 169 & 172 & 127 & 114 & 151 \\
\hline Vaccinio-Piceetea & 30 & 24 & 17 & 19 & 33 & 26 & 28 & 27 & 15 & 19 & 17 & 26 & 23 \\
\hline Fagetalia sylvaticae & 25 & 23 & 24 & 17 & 16 & 16 & 13 & 13 & 14 & 14 & 15 & 9 & 7 \\
\hline Mulgedio-Aconitetea & 16 & 19 & 15 & 19 & 11 & 13 & 14 & 10 & 6 & 7 & 9 & 9 & 9 \\
\hline Erico-Pinetea & 6 & 7 & 8 & 9 & 8 & 9 & 9 & 10 & 11 & 9 & 12 & 14 & 13 \\
\hline Aremonio-Fagion & 6 & 9 & 11 & 10 & 8 & 9 & 6 & 7 & 8 & 6 & 7 & 4 & 6 \\
\hline Asplenietea trichomanis & 3 & 2 & . & 3 & 6 & 8 & 11 & 10 & 8 & 10 & 11 & 10 & 10 \\
\hline Other species & 8 & 13 & 7 & 11 & 5 & 3 & 4 & 6 & 7 & 9 & 5 & 4 & 5 \\
\hline Querco-Fagetea & 2 & 2 & 13 & 7 & 6 & 5 & 7 & 3 & 13 & 5 & 6 & 4 & 3 \\
\hline Elyno-Seslerietea & 2 & 1 & 1 & 3 & 3 & 4 & 3 & 7 & 4 & 8 & 5 & 8 & 10 \\
\hline Thlaspietea rotundifolii & 3 & 2 & 3 & 2 & 3 & 5 & 5 & 6 & 3 & 5 & 5 & 5 & 8 \\
\hline Quercetalia pubescentis & . & . & 1 & 1 & 2 & 1 & 1 & 2 & 8 & 4 & 5 & 3 & 2 \\
\hline Quercetalia roboris-petraeae & . & . & . & . & . & . & . & . & 3 & 2 & 2 & 2 & 2 \\
\hline Festuco-Brometea & . & . & . & . & . & . & . & . & 2 & 2 & 2 & 3 & 2 \\
\hline
\end{tabular}


H-Frh) since they thrive on their upper elevational limit, in close contact with subalpine beech stands and in very similar ecological conditions (compare also Dakskobler et al. 2000). The reason why stands of pre-alpine fir-beech forests with $\mathrm{R}$. hirsutum ( $\mathrm{Ho}$ mogyno-Fagetum s. lat. rhododendretosum) clustered so separately from other subalpine beech stands might be explained by their close proximity to the Julian Alps and thus by the large proportion of SE-Alpine taxa. Comparison of phytosociological groups in (fir-) beech syntaxa with Hairy Alpenrose (Rhododendron hirsutum) in the Julian Alps and Dinaric Mts showed several distinctions and significantly explained the cluster topology: species of the Erico-Pinetea, Asplenietea and Elyno-Seslerietea were most frequently represented in RhododendroFagetum and Homogyno-Fagetum rhododendretosum. Furthermore, species of the Festuco-Brometea and the Quercetalia roboris-petraeae were present only in stands of Homogyno-Fagetum and Rhododendro-Fagetum, while species of the Quercetalia pubescentis were most frequent in stands of Rhododendro-Fagetum. These stands, although physiognomically resembling Polysticho-Fagetum rhododendretosum, are characterised by the presence of thermophilous taxa and floristic richness, indicating more moderate ecological conditions as a consequence of thriving at lower altitudes. Typically among beech forests, species of the Vaccinio-Piceetea are most frequent in fir-beech forests (Omphalodo-Fagetum s. lat., Homogyno-Fagetum s. lat.). Generaly, tall herbs (MulgedioAconitetea) were more frequent in subalpine beech stands (Polysticho lonchitis-Fagetum).

In terms of phytosociological groups, subalpine beech stands with Hairy Alpenrose differ from other subalpine beech stands in hosting a smaller number of the Fagetalia sylvaticae (Aremonio-Fagion) and the Mulgedio-Aconitetea species, but a higher number of Asplenietea trichomanis species, the latter due to the higher proportion of stoniness.

Interestingly, certain subalpine beech stands from Austria (Saxifrago-Fagetum calamagrostietosum and typicum) clustered together with stands of Polysticho-Fagetum from the SE Alps and Dinaric Mts, while other, more mesophilic stands, formed a distinct cluster (Figs. $2 \& 3$ ).

According to Willner (2002, 2007), subalpine (Polysticho lonchitis-Fagetum) and altimontane ( $R a-$ nunculo platanifolii-Fagetum) beech stands from the SE Alps and Dinaric Mts from the alliance Aremonio-Fagion show no significant floristical differences from the Central-European subalpine and altimontane beech stands (alliance Fagion sylvaticae).
Therefore, according to the nomenclature code (Weber et al. 2000) and principle of priority, they should be treated as Saxifrago rotundifoliae-Fagetum Zukrigl 1989. However - our analysis, although not comprehensive enough - does not fully support this statement. Only thorough and extensive analysis covering Central European and SE European beech stands could solve the problem of the syntaxonomic position of alliances (Fagion sylvaticae vs. Aremonio-Fagion).

Nevertheless, we classified subalpine beech stands with Hairy Alpenrose into a new subassociation Polysticho lonchitis-Fagetum rhododendretosum hirsuti, and as differential species for the subassociation we chose Rhododendron hirsutum, Rubus saxatilis, Rosa pendulina, and Clematis alpina (Tab. 1). As inferred from Figs. 1-3, relevés 1-5 from the phytosociological table of Polysticho-Fagetum var. geogr. Allium victorialis (Marinček 1996, cluster $\mathrm{Ib}-5)$ were included into the new subassociation -rhododendretosum hirsuti, since the differential species (Polystichum lonchitis for the subassociation and Gymnocarpium dryopteris, Solidago virgaurea, Vaccinium vitis-idaea for the variant) of the previously described subassociation and variant (-polystichetosum var. Gymnocarpium robertianum) were not most accurately chosen, and do not fully indicate specific ecological conditions of the selective stands. As inferred from our synoptic table and numerical analyses (but also field diagnostics) those relevés do not represent a "typicum" but rather distinct stands with a particular floristic combination, frequency and coverage of differential species, indicating unfavourable ecological conditions.

While classification of the studied stands within subalpine beech stands was not questionable, delimitation of stands of syntaxa Polysticho-Fagetum s. lat. and Ranunculo platanifolii-Fagetum s. lat., specially in terms of good characteristic and differential species, is less conspicuous and in many cases (according to our personal observations and while comparing available phytosociological data, partly also following judgments of Horvat (1938) and Tomažič $(1958,1959)$ - see the introduction) the distinction between stands of the two syntaxa was based till now most frequently on their physiognomy rather than floristic principles, since appropriate characteristic and differential species are hard to define. Therefore only a thorough synoptic approach taking into account all (fir-) beech stands of the Illyrian floral province would properly challenge the current syntaxonomy. Although much beyond the scope of the present treatise, we sug- 
gest reconsidering the present synsystematics of subalpine-altimontane beech stands of the alliance Aremonio-Fagion and possibly trying to define them with the help of altitudinal variants. Additionally, and as already pointed out, the geographical delimitation of subalpine beech syntaxa in terms of different geographical variants proved to be of no significant synsystematic value (e.g. figs. 1-3). We classified the studied stands as follows:

Querco-Fagetea Br.-Bl. et Vlieg. 1937

Fagetalia sylvaticae Pawl. 1928

Aremonio-Fagion (Horvat 1938) Borhidi in

Török, Podani et Borhidi 1989

Polysticho lonchitis-Fagetum (Horvat 1938)

Marinček in Poldini \& Nardini 1993

rhododendretosum hirsuti Surina subass. nova

Nomenclatural type for the subassociation Polysticho lonchitis-Fagetum rhododendretosum hirsuti subass. nova: relevé no. 4 in table 1, holotypus hoc loco.

Generally, stands of the Polysticho-Fagetum rhododendretosum on the Snežnik plateau are neither frequent nor do they extend over larger areas. Although subalpine beech stands are quite widespread throughout the plateau, we found stands with prevailing Rhododendron hirsutum in the undergrowth only on extreme sites, namely: western and north-western slopes of the dolina of Stanišče, northerly exposed slopes between Lom and Kapetanova bajta (above the dolinas of Grda draga and Pekel), in the area of forest reserves of Planinc-Zatrep and Ždrocle, on ridges above dolinas of Grdobe and Medvedje doline, in the vicinity of Herbade above the dolina of Ilovca, and on the ridge west from Mt. Žaknovec. As a rule, stands of subalpine beech forest (Polysticho-Fagetum s. lat.) do not have a significant role in wood exploitation, although till the middle of the $20^{\text {th }}$ century these stands were (mostly due to suitable trunk diameter) abundantly used for charcoal-burning. Nevertheless, their indispensable forest protective function has been recognized for a long time.

\section{CONCLUSIONS}

(a) Subalpine beech stands with Hairy Alpenrose (Rhododenron hirsutum) are floristically and ecologically quite distinct from other subalpine beech stands of the association Polysticho lonchitis-Fagetum s. lat. (b) Therefore, on the basis of the synoptic table, numerical analyses, and according to the current synsystematics of subalpine beech syntaxa of the Illyrian floral province, we classified them into the new subassociation Polysticho-Fagetum rhododendretosum hirsuti subass. nova (alliance Aremonio-Fagion). Differential species of the subassociation (Rhododendron hirsutum, Rubus saxatilis, Rosa pendulina, and Clematis alpina) sufficiently illustrate the ecological peculiarities of their sites. (c) Stands thrive on ecologically unfavourable growth sites, e.g. steep, rocky and northerly exposed slopes with heavy and long-lasting snow cover, and ridges exposed to strong Bora. (d) Stands of the Polysticho-Fagetum rhododendretosum subass. nova on the Snežnik plateau are neither frequent nor do they extend over larger areas. Till now they were observed only on the southern part of the plateau.

\section{ACKNOWLEDGMENTS}

The author thanks I. Dakskobler and P. Košir for many valuable discussions and helpful suggestions that improved the manuscript.

\section{APPENDIX}

\section{Localities of relevés:}

Slovenia, Dinaric Mts, Liburnian karst, Snežnik plateau:

1-3, 9 - Stanišče, 24. 7. 2002, leg. B. Surina.

4, 5, 7, 8, 10, 11 - Kapetanova bajta, 26. 7. 2005, leg. B. Surina.

6 - Ilovca (SW from Herbade), 29. 7. 2005, leg. B. Surina.

2. List of syntaxa

- Adenostyletalia G. Br.-Bl. \& J. Br.-Bl. 1931

- Allio victorialis-Fagetum (Tomažič 1958) Accetto 2002 nom. inval.

- Aremonio-Fagion (Horvat 1938) Borhidi in Török, Podani \& Borhidi 1989

- Asplenietea trichomanis Br.-Bl. in Meier \& Br.-Bl. 1934

- Elyno-Seslerietea Br.-Bl. 1948

- Erico-Pinetea Horvat 1959

- Fagetalia sylvaticae Pawl. 1928

- Fagion sylvaticae Luquet 1926

- Homogyno sylvestris-Fagetum Marinček et al. 1993 rhododendretosum hirsuti Dakskobler 2004

- Hyperico grisebachii-Pinetum mugo Zupančič et al. 2004 var. geogr. Arabis scopoliana Zupančič et al. 2004 
- Mulgedio-Aconitetea Hadač \& Klika in Klika \& Hadač 1944

- Omphalodo-Fagetum (Tregubov 1957 corr. Puncer 1980) Marinček et al. 1993 var. geogr. Saxifraga cuneifolia Surina 2002 rhododendretosum hirsuti Dakskobler et al. 2000

- Polysticho lonchitis-Fagetum (Horvat 1938) Marinček in Poldini \& Nardini 1993 rhododendretosum hirsuti Surina 2007

- Quercetalia pubscentis Klika 1933

- Querco-Fagetea Br.-Bl. \& Vlieg. 1937

- Ranunculo platanifolii-Fagetum Marinček et al. 1993

- Rhododendro hirsuti-Fagetum Accetto ex Dakskobler 1998 var. geogr. Anemone trifolia Dakskobler 1998

- Rhododendro hirsuti-Fagetum Accetto ex Dakskobler 1998 var. geogr. Phyteuma columnae Dakskobler nom. prov.

- Saxifrago rotundifoliae-Fagetum Zukrigl 1989 s. lat.

- Seslerion juncifoliae Horvat 1962

- Thlaspietea rotundifolii $\mathrm{Br}$.-Bl. in Br.-Bl. \& Jenny 1926

- Vaccinio-Piceetea Br.-Bl. 1939 emend. Zupančič (1976) 2000

\section{REFERENCES}

Braun-Blanquet, J. 1964: Pflanzensoziologie. Grundzüge der Vegetationskunde. 3. Auflage. Springer, Wien - New York, 865 pp.

Dakskobler, I. 1997: Geografske variante asociacije Seslerio autumnalis-Fagetum (Ht.) M. Wraber ex Borhidi 1963. Razprave IV. razreda SAZU 38 (8): 165-255.

Dakskobler, I. 2002: Jelovo-bukovi gozdovi na Bovškem (Julijske Alpe, severozahodna Slovenija). Razprave IV. razreda SAZU 43 (2): 109-155.

Dakskobler, I. 2003: Asociacija Rhododendro hirsutiFagetum Accetto ex Dakskobler 1998 v zahodni Sloveniji. Razprave IV. razreda SAZU 44 (2): 5-85.

Dakskobler, I. 2004: Jelovo-bukovi gozdovi v dolini Loške Koritnice v Julijskih Alpah (severozahodna Slovenija). Gozdarski vestnik 62 (7-8): 299-315.

Dakskobler, I., Urbančič, M. \& Wraber, A. 2000: Gozd bukve in jelke z dlakavim slečem Omphalodo-Fagetum (Tregubov 1957) Marinček et al. 1993 rhododendretosum hirsuti (Urbančič et al. 1979 nom. nud.) subass. nova v Trnovskem gozdu (zahodna Slovenija). Zbornik gozdarstva in lesarstva 62: 5-52.

Dierschke, H. 1994: Pflanzensoziologie. Eugen Ulmer, Stuttgart, 683 pp.

Horvat, I., 1938: Biljnosociološka istraživanja šuma u Hrvatskoj. Glasnik za šumske pokuse 6: 127-256.

Kindler, V. 1957: Zgodovina snežniških gozdov. In: Tregubov, V. \& Čokl, M. (eds.): Prebiralni gozdovi na Snežniku. Ljubljana, pp. 81-84.

Košir, Ž. 1979: Ekološke, fitocenološke in gozdnogospodarske lastnosti Gorjancev v Sloveniji. Zbornik gozdarstva in lesarstva 17 (1): 1-242.

Manohin, V. 1957: Podnebje Snežnika in okolice. In: Tregubov, V. \& Čokl, M. (eds.): Prebiralni gozdovi na Snežniku. Ljubljana, pp. 17-22.

Marinček, L. 1980: Subalpsko bukovje Śkofjeloškega hribovja. Loški razgledi 27: 182-192.

Marinček, L. 1983: Klimatogene bukove združbe v Sloveniji. Ekologija 18 (1): 1-13.

Marinček, L. 1996: Subalpine Buchewälder in den Westlichen Dinariden (Polysticho lonchitis-Fagetum var. geogr. Allium victorialis var. geogr. nova). Annali dei Musei Civici di Rovereto. Sez.: Arch., St., Sc.nat.Suppl.II 11: 197-208.

Marinček, L. 1998: Hochmontane Buchenwälder Illyriens. Annales, Series historia naturalis 13: 103-108.

Marinček, L., Mucina, L., Zupančič, M., Poldini, L., Dakskobler, I. \& Accetto, M., 1993: Nomenklatorische Revision der illyrischen Buchenwälder (Verband Aremonio-Fagion). Studia Geobotanica 12 (1992): 121-135.

Martinčič, A. 2003: Seznam listnatih mahov (Bryopsida) Slovenije. Hacquetia 2 (1): 91-166.

Martinčič, A., Wraber, T., Jogan, N., Ravnik, V., Podobnik, A., Turk, B. \& Vreš, B. 1999: Mala flora Slovenije. Tehniška založba Slovenije, Ljubljana, 845 pp.

Mekinda-Majaron, T. 1995: Klimatografija Slovenije, temperature zraka, obdobje 1960-1990. Ministrstvo za okolje in prostor, Hidrometeorološki zavod Republike Slovenije, Ljubljana, 356 pp.

Pavlovec, R. \& Pleničar, M. 2000: Kako je nastajal Snežnik. In: Čeligoj, V. (ed.): Knjiga o Snežniku. Ilirska Bistrica, pp. 10-13.

Pleničar, M. 1956: Geološki izlet na Snežnik. Proteus 19 (1): 16-18.

Podani, J. 2001: SYN-TAX 2000. Computer programs for data analysis in ecology and systematics. Budapest, 53 pp.

Pogačnik, N. \& Prosen, M., 1998: Zgradba bukovega gozda ob zgornji gozdni meji na Snežniku. Gozdarski vestnik 56 (10): 443-459. 
Poldini, L. \& Nardini, S., 1993: Boschi di forra, faggete e abieteti in Friuli. Studia Geobotanica 13: 215-298.

Šifrer, M. 1959: Obseg pleistocenske poledenitve na Notranjskem Snežniku. Geografski zbornik 5: 27-80.

Smerdel, I. 1989: Ovčarstvo na Pivki: transhumanca od srede 19. stol. do srede 20. stoletja ali trije "ovčarji". Lipa, Koper, 157 pp.

Suppan, U., Prügger, J. \& Mayrhofer, H., 2000: Catalogue of the lichenized and lichenicolous fungi of Slovenia. Bibliotheca Lichenologica 76 : 5-215.

Surina, B. \& Vreš, B., 2004: Phytsociological characteristics of sites of Heliosperma pusillum (=Silene pusilla, Caryophyllaceae) in the freezing ravines on the Snežnik Plateau (SW Slovenia). Razprave IV. razreda SAZU 45 (2): 147-183.

Tomažič, G. \& Tregubov, V. 1958: Tabelarni pregled gozdnih tipov. In: Tregubov, V. (ed.): Gozdno gojitveni elaborat ma osnovi gozdnih tipov za revir Gomance. Elaborat. Ljubljana, pp. 30.

Tomažič, G. \& Tregubov, V. 1959: Tabelarni pregled gozdnih tipov revirja Okroglina. In: Tregubov, V. (ed.): Gozdno gojitveni elaborat na osnovi gozdnih tipov za revir Okroglina. Elaborat. Ljubljana, pp. 35.

Tregubov, V. 1957: Gozdne rastlinske združbe. In: Tregubov, V. \& Čokl, M. (eds.): Prebiralni gozdovi na Snežniku. Ljubljana, pp. 23-65.

van der Maarel, E. 1979: Transformation of coverabundance values in phytosociology and its effects on community similarity. Vegetatio 39 (2): 97-114.
Weber, H. E., Moravec, J. \& Theurillat, J.-P. 2000: International Code of Phytosociological Nomenclature. 3rd edition. Journal of Vegetation Science 11 (5): 739-768.

Willner, W. 2002: Syntaxonomische Revision der südmitteleuropäischen Buchenwälder. Phytocoenologia 32 (3): 337-453.

Willner, W. 2007: Fagion sylvaticae Luquet 1926. In: Willner, W. \& Grabherr, G. (eds.): Die Wälder und Gebüsche Österreichs. 1 Textband. München, pp. 144-166.

Willner, W. \& Grabherr, G. 2007: Die Wälder und gebüsche Österreichs. 2 Tabellenband. Elsevier GmbH, Spektrum Akademischer Verlag, München, 290 pp.

Wraber, T. 1997: Snežnik - gora (tudi) za botanike. Proteus 59 (9-10): 408-421.

Zupančič, B. 1995: Klimatografija Slovenije, količina padavin, obdobje 1960-1990. Ministrstvo za okolje in prostor, Hidrometeorološki zavod Republike Slovenije, Ljubljana, 366 pp.

Zupančič, M. 1970: Vegetacijski profil Snežniškega pogorja. In: Brdnik, J., Pavlovec, R.\& Prvinšek, L. (eds.): Mladinski raziskovalni tabori 1970. Ljubljana, pp. 66-91.

Zupančič, M. 1980: Smrekovi gozdovi v mraziščih dinarskega gorstva Slovenije. Biološki inštitut Jovana Hadžija, ZRC SAZU, Ljubljana, 262 pp.

Zupančič, M. 2001: Vegetacijska raziskovanja G. Tomažiča na Notranjskem Snežniku. Hladnikia 12-13: 31-39.

Recieved 26. 2. 2007

Revision recieved 13. 11. 2007

Accepted 19. 11. 2007

For Appendix. 1, see Hacquetia Electronic Archives; http://www.versita.com/science/lifesciences/hacquetia 
Table 1: Phytosociological table of the subalpine beech stands with Hairy Alpenrose (Rhododendron hirsutum) on Mt. Snežnik.

Tabela 1: Analizna tabela subalpinskih bukovih sestojev z dlakavim slečem (Rhododendron hirsutum) na Snežniku.

\begin{tabular}{|c|c|c|c|c|c|c|c|c|c|c|c|c|c|c|c|}
\hline Succesive number & & & 1 & 2 & 3 & $4^{*}$ & 5 & 6 & 7 & 8 & 9 & 10 & 11 & & \\
\hline Altitude (m) & & & 1310 & 1330 & 1310 & 1420 & 1420 & 1340 & 1440 & 1430 & 1340 & 1390 & 1390 & & \\
\hline Exposition & & & $\mathrm{N}$ & $\mathrm{N}$ & $\mathrm{NE}$ & NNW & $\mathrm{N}$ & $\mathrm{N}$ & $\mathrm{N}$ & $\mathrm{N}$ & $\mathrm{N}$ & $\mathrm{N}$ & $\mathrm{N}$ & & \\
\hline Inclination $\left({ }^{\circ}\right)$ & & & 35 & 35 & 35 & 30 & 40 & 30 & 25 & 15 & 45 & 40 & 50 & & \\
\hline Relevé area $\left(\mathrm{m}^{2}\right)$ & & & 400 & 400 & 400 & 400 & 400 & 400 & 400 & 400 & 400 & 400 & 400 & & \\
\hline Stoniness $(\%)$ & & & 10 & 40 & 25 & 40 & 40 & 50 & 20 & 50 & 40 & 20 & 70 & & \\
\hline Cover $(\%)$ & Tree layer & A & 90 & 90 & 95 & 95 & 90 & 90 & 80 & 80 & 80 & 95 & 80 & & \\
\hline & Shrub layer & B & 10 & 10 & 10 & 10 & 5 & 5 & 1 & 5 & 30 & 40 & 60 & & \\
\hline & Herb layer & $\mathrm{C}$ & 80 & 80 & 70 & 60 & 50 & 40 & 70 & 50 & 60 & 70 & 30 & & \\
\hline & Moss layer & $\mathrm{D}$ & 5 & 20 & 5 & 10 & 5 & 5 & 5 & 5 & 20 & 5 & 10 & & \\
\hline No. of seed plants & & & 54 & 49 & 41 & 56 & 55 & 45 & 57 & 47 & 35 & 40 & 40 & Fr. & $\%$ \\
\hline \multicolumn{16}{|c|}{ Character and differential species of the association } \\
\hline Polystichum lonchitis & & $\mathrm{C}$ & + & + & + & 1 & + & 1 & + & + & + & + & 1 & 11 & 100 \\
\hline \multirow{2}{*}{ Salix appendiculata } & & $\mathrm{B}$ & . & . & . & + & + & + & . & + & . & + & 1 & \multirow{2}{*}{8} & \\
\hline & & $\mathrm{C}$ & . & . & . & + & . & . & + & . & + & . & + & & 73 \\
\hline Carex ferruginea & & $\mathrm{C}$ & + & . & . & + & + & . & 1 & + & . & . & . & 5 & 45 \\
\hline Lonicera caerulea & & $\mathrm{C}$ & . & + & . & . & + & . & + & + & . & . & . & 4 & 36 \\
\hline \multirow{2}{*}{ Ribes alpinum } & & $\mathrm{B}$ & . & + & . & + & . & . & . & . & . & . & . & 4 & 36 \\
\hline & & $\mathrm{C}$ & . & . & + & . & . & . & . & . & . & . & + & 2 & 18 \\
\hline
\end{tabular}

Differential species of the subassociation rhododendretosum hirsuti

\begin{tabular}{|c|c|c|c|c|c|c|c|c|c|c|c|c|c|c|}
\hline EP Rhododendron hirsutum & $\mathrm{C}$ & 1 & 3 & 3 & 3 & 2 & 3 & 3 & 3 & 4 & 3 & 3 & 11 & 100 \\
\hline EP Rubus saxatilis & $\mathrm{C}$ & 2 & 1 & + & 1 & 1 & 1 & 1 & 2 & 1 & 2 & 1 & 11 & 100 \\
\hline VP Clematis alpina & $\mathrm{C}$ & 1 & 2 & 2 & 2 & 2 & 2 & 2 & 2 & 2 & 2 & 2 & 11 & 100 \\
\hline \multirow{2}{*}{ Rosa pendulina } & B & . & 1 & . & + & 1 & + & . & . & . & 1 & 1 & \multirow{2}{*}{11} & \multirow{2}{*}{100} \\
\hline & $\mathrm{C}$ & 2 & 2 & 2 & 2 & 2 & 2 & 2 & 2 & 1 & 3 & 2 & & \\
\hline \multicolumn{15}{|l|}{ Aremonio-Fagion } \\
\hline Cardamine enneaphyllos & $\mathrm{C}$ & + & + & + & + & + & 1 & + & + & + & + & + & 11 & 100 \\
\hline Euphorbia carniolica & $\mathrm{C}$ & + & + & . & + & + & + & + & + & + & + & + & 10 & 91 \\
\hline Cardamine trifolia & $\mathrm{C}$ & 1 & . & . & + & + & 1 & + & + & . & + & + & 8 & 73 \\
\hline Hacquetia epipactis & $\mathrm{C}$ & . & + & 1 & . & . & . & + & + & . & . & . & 4 & 36 \\
\hline Cyclamen purpurascens & $\mathrm{C}$ & . & . & . & . & . & . & . & + & 1 & . & . & 2 & 18 \\
\hline Vicia oroboides & $\mathrm{C}$ & + & . & . & . & . & . & + & . & . & . & . & 2 & 18 \\
\hline Rhamnus fallax & B & . & . & + & . & . & . & . & . & . & . & . & 1 & 9 \\
\hline Omphalodes verna & $\mathrm{C}$ & + & . & . & . & . & . & . & . & . & . & . & 1 & 9 \\
\hline \multirow[t]{2}{*}{ FS Fagetalia sylvaticae } & & & & & & & & & & & & & & \\
\hline & A & 5 & 5 & 5 & 5 & 5 & 5 & 5 & 5 & 4 & 5 & 5 & \multirow{3}{*}{11} & \multirow{3}{*}{100} \\
\hline \multirow[t]{2}{*}{ Fagus sylvatica } & B & + & + & 1 & 1 & + & + & + & 1 & 3 & 2 & 2 & & \\
\hline & $\mathrm{C}$ & + & + & + & 1 & + & + & + & + & + & . & + & & \\
\hline \multirow{2}{*}{ Lonicera alpigena } & B & + & + & . & 1 & + & . & . & 1 & . & 1 & . & \multirow{2}{*}{11} & \multirow{2}{*}{100} \\
\hline & $\mathrm{C}$ & + & + & + & . & + & + & 1 & 1 & 1 & 2 & 2 & & \\
\hline \multirow{2}{*}{ Dahpne mezereum } & B & + & + & 1 & + & + & . & + & . & + & 1 & . & \multirow{2}{*}{10} & \multirow{2}{*}{91} \\
\hline & $\mathrm{C}$ & . & + & 1 & + & + & + & . & + & + & + & . & & \\
\hline Festuca altissima & $\mathrm{C}$ & + & + & + & 1 & 1 & . & 1 & . & 1 & + & 1 & 9 & 82 \\
\hline Mercurialis perennis & $\mathrm{C}$ & 1 & 1 & + & + & 1 & + & 1 & + & . & 1 & . & 9 & 82 \\
\hline Prenanthes purpurea & $\mathrm{C}$ & + & + & . & + & + & + & + & . & + & + & + & 9 & 82 \\
\hline
\end{tabular}


Succesive number

\begin{tabular}{lllllllllll}
1 & 2 & 3 & $4 *$ & 5 & 6 & 7 & 8 & 9 & 10 & 11 \\
\hline
\end{tabular}

Acer pseudoplatanus

Epilobium montanum

Symphytum tuberosum

Ranunculus platanifolius

Helleborus niger

Actaea spicata

Dryopteris filix-mas

Geranium robertianum

Mycelis muralis

Adoxa moschatelina

Lilium martagon

Aruncus dioicus

Galium sylvaticum

Lathyrus vernus

\begin{tabular}{|c|c|c|c|c|c|c|c|c|c|c|c|}
\hline A & . & + & + &. & . & . & r & . & + & . & . \\
\hline $\mathrm{C}$ & + & + & + & + & + & + & . & . & + & . & \\
\hline $\mathrm{C}$ & . & + & . & + & + & . & + & . & . & . & \\
\hline $\mathrm{C}$ & 1 & . & . & . & + & + & + & . & . & . & \\
\hline $\mathrm{C}$ & + & . & + & + & . & + & + & . & . & . & \\
\hline $\mathrm{C}$ & . & . & 1 & . & . & . & + & + & . & . & \\
\hline $\mathrm{C}$ & + & + & . & + & . & + & . & . & . & . & \\
\hline $\mathrm{C}$ & + & + & . & . & . & . & + & . & . & . & \\
\hline $\mathrm{C}$ & + & . & . & . & . & . & . & + & . & + & \\
\hline $\mathrm{C}$ & . & . & . & . & + & . & + & . & . & . & \\
\hline $\mathrm{C}$ & + & . & . & + & . & . & . & . & & & \\
\hline $\mathrm{C}$ & . & . & . & . & . & . & + & . & . & + & \\
\hline $\mathrm{C}$ & . & . & . & + & . & . & . & . & . & . & \\
\hline $\mathrm{C}$ & . & . & + & . & . & . & . & . & . & . & \\
\hline $\mathrm{C}$ & . & . & . & . & . & . & + & . & . & . & \\
\hline
\end{tabular}

QP Quercetalia pubescentis

Sorbus aria

$\begin{array}{lllllllllllllll}\mathrm{A} & \cdot & + & + & + & \cdot & \cdot & + & \cdot & + & + & \cdot & & \\ \mathrm{B} & + & \cdot & \cdot & + & \cdot & \cdot & \cdot & + & + & + & + & 9 & \mathbf{8 2}\end{array}$

QF Querco-Fagetea

Anemone nemorosa

Carex digitata

Convalaria majalis

Hepatica nobilis

Dactylorhiza maculata

Poa nemoralis

MA Mulgedio-Aconitetea

Veratrum album subsp. album

Phyteuma ovatum

Polygonatum verticillatum

Pleurospermum austriacum

Athyrium filix-femina

Viola biflora

Aconitum ranunculifolium

Allium victorialis

Saxifraga rotundifolia

Cirsium waldsteinii

$\begin{array}{llllllllllllll}\mathrm{C} & 1 & 2 & 1 & 1 & 1 & 1 & 2 & 2 & 1 & 2 & 2 & 11 & \mathbf{1 0 0}\end{array}$

$\mathrm{C}+$..++ . . . . . 54

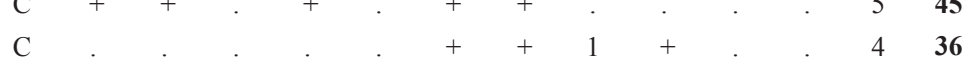

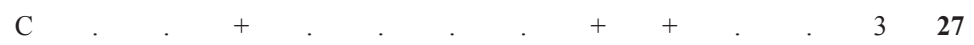

$\mathrm{C}+$. . . . . . . . . . 278

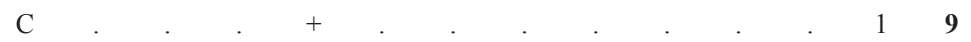

P Vaccinio-Piceetea

Valeriana tripteris

Homogyne sylvestris

Gentiana asclepiadea

Solidago virgaurea

Abies alba

Vaccinium myrtillus

Maianthemum bifolium

Huperzia selago

Aposeris foetida

Veronica urticifolia

Hieracium murorum agg.

\begin{tabular}{|c|c|c|c|c|c|c|c|c|c|c|c|c|c|}
\hline $\mathrm{C}$ & 1 & + & + & + & + & + & + & + & + & + & + & 11 & 100 \\
\hline $\mathrm{C}$ & 1 & 1 & 1 & 2 & 1 & + & + & . & 1 & 1 & 1 & 10 & 91 \\
\hline C & + & + & + & + & + & + & 1 & 1 & . & . & . & 8 & 73 \\
\hline $\mathrm{C}$ & . & . & . & . & . & . & + & + & . & + & . & 3 & 27 \\
\hline $\mathrm{C}$ & . & . & . & . & + & . & . & . & . & + & . & 2 & 18 \\
\hline C & . & . & . & . & + & + & . & . & . & . & . & 2 & 18 \\
\hline $\mathrm{C}$ & . & . & . & . & . & . & . & + & . & . & . & 1 & 9 \\
\hline $\mathrm{C}$ & . & . & . & . & . & . & 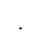 & + & . & . & . & 1 & 9 \\
\hline $\mathrm{C}$ & . & + & . & . & . & . & . & . & . & . & . & 1 & 9 \\
\hline $\mathrm{C}$ & + & . & . & . & . & . & . &. & . & . & . & 1 & 9 \\
\hline
\end{tabular}

\begin{tabular}{|c|c|c|c|c|c|c|c|c|c|}
\hline $\mathrm{C}$ & 1 & 1 & 1 & 2 & 1 & + & 1 & 1 & \\
\hline $\mathrm{C}$ & 1 & 1 & 1 & 2 & 1 & 1 & 1 & 1 & \\
\hline $\mathrm{C}$ & 1 & + & + & + & + & + & + & 1 & \\
\hline $\mathrm{C}$ & + & + & . & + & + & + & + & - & \\
\hline A & . & + & . & . & . & . & . & . & \\
\hline B & + & 1 & + & . & + & . & . & . & \\
\hline $\mathrm{C}$ & . & 1 & . & + & + & . & . & . & \\
\hline $\mathrm{C}$ & . & 1 & . & . & + & 1 & 1 & 2 & \\
\hline $\mathrm{C}$ & + & + & + & + & + & + & 1 & $t$ & \\
\hline $\mathrm{C}$ & + & + & . & + & + & + & + & & \\
\hline $\mathrm{C}$ & 2 & 1 & + & . & . & . & . & & \\
\hline $\mathrm{C}$ & + & . & + & 1 & 1 & . & . & & \\
\hline $\mathrm{C}$ & . & . & + & + & + & + & . & & \\
\hline
\end{tabular}




\begin{tabular}{|c|c|c|c|c|c|c|c|c|c|c|c|c|c|c|}
\hline Succesive number & & 1 & 2 & 3 & $4 *$ & 5 & 6 & 7 & 8 & 9 & 10 & 11 & & \\
\hline Vaccinium vitis-idaea & $\mathrm{C}$ & . & . & + & + & + & . & . & 2 & . & . & . & 4 & 36 \\
\hline Dryopteris dilatata & $\mathrm{C}$ & + & + & . & + & + & . & . & . & . & . & . & 4 & 36 \\
\hline \multirow[t]{2}{*}{ Luzula sylvatica } & $\mathrm{C}$ & + & . & . & + & + & . & + & . & . & . & . & 4 & 36 \\
\hline & A & . & . & . & . & . & + & . & . & . & . & . & & \\
\hline \multirow[t]{2}{*}{ Picea abies } & $\mathrm{B}$ & . & . & . & + & . & + & . & . & . & . & . & 4 & 36 \\
\hline & $\mathrm{C}$ & + & + & . & . & . & . & + & . & . & . & . & & \\
\hline Gymnocarpium dryopteris & $\mathrm{C}$ & + & 1 & . & . & . & . & . & . & 1 & . & . & 3 & 27 \\
\hline Oxalis acetosella & $\mathrm{C}$ & 1 & + & . & . & + & + & . & . & . & . & . & 4 & 36 \\
\hline Laserpitium krapfii & $\mathrm{C}$ & . & . & . & . & . & . & . & + & . & + & . & 2 & 18 \\
\hline Thelypteris phegopteris & $\mathrm{C}$ & . & . & . & . & + & . & . & . & . & . & + & 2 & 18 \\
\hline \multicolumn{15}{|l|}{ Erico-Pinetea } \\
\hline Calamagrostis varia & $\mathrm{C}$ & 2 & 1 & 1 & 1 & 1 & . & 2 & 2 & 1 & 2 & 1 & 10 & 91 \\
\hline Cirsium erisithales & $\mathrm{C}$ & + & + & + & + & . & + & + & . & 1 & + & . & 8 & 73 \\
\hline Aquillegia nigricans & $\mathrm{C}$ & + & + & + & . & . & . & + & + & . & . & . & 5 & 45 \\
\hline Erica herbacea & $\mathrm{C}$ & . & . & . & . & . & . & . & + & . & + & . & 2 & 18 \\
\hline Juniperus sibirica & $\mathrm{C}$ & . & . & . & . & . & . & . & + & . & + & . & 2 & 18 \\
\hline \multicolumn{15}{|l|}{ Elyno-Seslerietea } \\
\hline Aster bellidiastrum & $\mathrm{C}$ & 1 & . & + & . & + & 1 & . & . & 1 & + & + & 7 & 64 \\
\hline Erigeron glabratus & $\mathrm{C}$ & . & . & . & . & . & . & + & . & . & . & . & 1 & 9 \\
\hline Heliosperma alpestre & $\mathrm{C}$ & . & . & . & + & . & . & . & . & . & . & . & 1 & 9 \\
\hline \multicolumn{15}{|l|}{ Asplenietea trichomanis } \\
\hline Asplenium viride & $\mathrm{C}$ & + & + & + & + & 1 & 1 & + & + & + & + & + & 11 & 100 \\
\hline Campanula justiniana & $\mathrm{C}$ & . & + & + & . & . & 1 & . & + & 1 & + & + & 7 & 64 \\
\hline Carex brachystachys & $\mathrm{C}$ & . & . & . & 1 & 1 & + & + & . & . & + & . & 5 & 45 \\
\hline Moehringia muscosa & $\mathrm{C}$ & . & . & . & . & + & + & + & . & . & . & + & 4 & 36 \\
\hline Cystopteris fragilis & $\mathrm{C}$ & . & + & . & + & + & + & . & . & . & . & . & 4 & 36 \\
\hline Cystopteris regia & $\mathrm{C}$ & . & . & . & . & + & . & + & . & . & . & + & 3 & 27 \\
\hline Asplenium ruta-muraria & $\mathrm{C}$ & . & . & . & . & + & + & . & . & . & . & + & 3 & 27 \\
\hline Asplenium trichomanes & $\mathrm{C}$ & . & . & . & . & . & . & . & . & . & . & + & 1 & 9 \\
\hline Festuca stenantha & $\mathrm{C}$ & . & . & . & + & . & . & . & . & . & . & . & 1 & 9 \\
\hline \multicolumn{15}{|l|}{ Thlaspietea rotundifolii } \\
\hline Adenostyles glabra & $\mathrm{C}$ & . & $\cdot$ & 1 & 2 & 2 & 1 & + & + & 1 & 1 & 1 & 9 & 82 \\
\hline Campanula cochleariifolia & $\mathrm{C}$ & . & . & . & 1 & + & . & + & + & . & . & . & 4 & 36 \\
\hline Gymnocarpium robertianum & $\mathrm{C}$ & . & . & . & + & + & + & + & . & . & . & + & 5 & 45 \\
\hline Dryopteris montana & $\mathrm{C}$ & . & . & . & + & . & . & . & . & . & . & . & 1 & 9 \\
\hline
\end{tabular}

OS Other species

Sorbus aucuparia

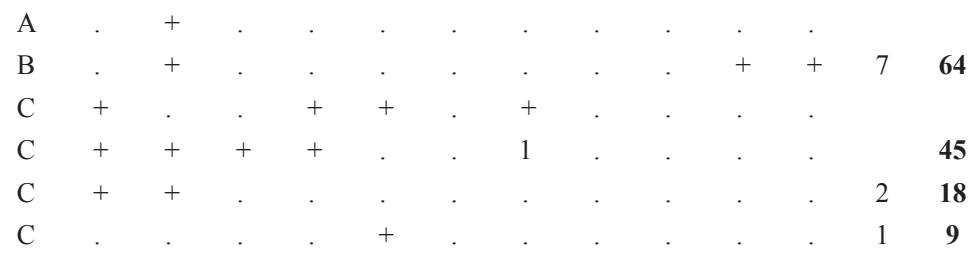

\section{ssia palustris}

Mosses and lichens

Ctenidium molluscum

Tortella tortuosa

Schistidium apocarpum

Fissidens cristatus

Cladonia pyxidata

Dicranum scoparium

Plagiochila asplenioides

Conocephalum conicum

$\begin{array}{llllllllllllll}\mathrm{D} & 2 & 1 & 1 & 2 & 2 & 2 & 2 & 2 & 2 & 2 & 2 & 11 & \mathbf{1 0 0} \\ \mathrm{D} & 1 & + & 1 & 1 & 1 & 1 & 1 & 1 & 1 & 1 & 1 & 11 & \mathbf{1 0 0} \\ \mathrm{D} & + & + & + & 1 & 1 & 1 & + & 1 & + & . & 1 & 10 & \mathbf{9 1} \\ \mathrm{D} & 1 & + & 1 & 1 & 1 & . & + & 1 & + & . & . & 8 & \mathbf{7 3} \\ \mathrm{D} & + & + & + & + & + & . & + & + & . & + & . & 8 & \mathbf{7 3} \\ \mathrm{D} & \cdot & 1 & + & . & + & . & + & + & + & . & + & 7 & \mathbf{6 4} \\ \mathrm{D} & . & . & + & + & . & 1 & . & 1 & . & + & 1 & 6 & \mathbf{5 5} \\ \mathrm{D} & + & + & + & . & . & . & + & . & . & . & . & 4 & \mathbf{3 6}\end{array}$




\begin{tabular}{|c|c|c|c|c|c|c|c|c|c|c|c|c|c|c|}
\hline Succesive number & & 1 & 2 & 3 & $4 *$ & 5 & 6 & 7 & 8 & 9 & 10 & 11 & & \\
\hline Peltigera leucophlebia & $\mathrm{D}$ & . & . & . & . & + & . & . & . & + & + & + & 4 & 36 \\
\hline Hypnum cupressiforme & $\mathrm{D}$ & 1 & + & + & . & . & . & . & . & . & . & . & 3 & 27 \\
\hline Brachythecium sp. & $\mathrm{D}$ & . & . & . & . & + & . & . & . & . & + & + & 3 & 27 \\
\hline Distichium capillaceum & $\mathrm{D}$ & . & . & . & + & + & 1 & . & . & . & . & . & 3 & 27 \\
\hline Pleurozium schreibersi & $\mathrm{D}$ & . & . & . & + & . & + & . & . & . & + & . & 3 & 27 \\
\hline Leptogium saturninum & $\mathrm{D}$ & . & . & . & + & + & . & . & . & . & . & . & 2 & 18 \\
\hline Rhytidiadelphus triquetrus & $\mathrm{D}$ & . & . & . & . & . & + & . & . & . & . & + & 2 & 18 \\
\hline Solorina saccata & $\mathrm{D}$ & . & . & + & . & . & . & . & . & . & . & + & 2 & 18 \\
\hline Bryum sp. & $\mathrm{D}$ & . & . & . & . & . & . & . & + & . & . & . & 1 & 9 \\
\hline Peltigera sp. & $\mathrm{D}$ & . & . & . & . & + & . & . & . & . & . & . & 1 & 9 \\
\hline Pohlia elongata/elongata & $\mathrm{D}$ & . & . & . & . & . & . & + & . & . & . & . & 1 & 9 \\
\hline Polytrichum alpinum & $\mathrm{D}$ & . & . & . & . & . & . & . & . & . & + & . & 1 & 9 \\
\hline Polytrichum commune & $\mathrm{D}$ & . & . & . & . & . & . & . & . & + & . & . & 1 & 9 \\
\hline
\end{tabular}

